\title{
An Integration of HF-AHP and ARAS Techniques in Supplier Selection: A Case Study in Waste Water Treatment Facility
}

\author{
Aşkın ÖZDAĞOĞLU ${ }^{1} \quad$ Kevser YILMAZ ${ }^{2}$ Elif ÇİRKİN ${ }^{3}$
}

\begin{abstract}
Issues regarding the supplier evaluation and selection have been proven troubsome in today's floruishing business world. However, decision making processes could be facilitated by such methods and techniques as HF-AHP and ARAS. This study aims to find the best supplier alternative among the five various machines offered by five suppliers according to four evaluation criterias by integrating HF-AHP with ARAS method.
\end{abstract}

Keywords: Production Management, HF-AHP Method, ARAS Method, Supplier Selection

JEL Classifications: M10, M11

\section{Tedarikçi Seçiminde HF-AHP ve ARAS Tekniğinin Entegrasyonu: Atık Su Arıtma Tesisinde Bir Vaka Çalışması}

\section{$\ddot{O z e t}$}

Tedarikçi değerlendirmesi ve seçimi ile ilgili konular günümüzün gelişen iş dünyasında sıkıntılı olduğu kanıtlanmıştır. Bununla birlikte, karar verme süreçleri HF-AHP ve ARAS gibi yöntem ve tekniklerle kolaylaştırllabilir..Bu çalışmanın amacı, $H F-A H P$ ve ARAS yöntemlerini entegre edilmesiyle beş farklı tedarikçi firmanın sunduğu beş farklı makine arasında dört farklı değerlendirme kriterinin bir arada göz önüne alınarak tercih yapılmasidır.

Anahtar Kelimeler: Üretim Yönetimi, HF-AHP Yöntemi, ARAS Yöntemi, Tedarikçi Seçimi

JEL Sınıflandırması: M10, M11

\footnotetext{
${ }^{1}$ Dokuz Eylul University, Faculty of Business, Division of Production Management and Marketing, Tinaztepe Campus, 35390 Buca-Izmir, askin.ozdagoglu@ deu.edu.tr

${ }^{2}$ Dokuz Eylul University, Faculty of Business, Division of Production Management and Marketing, Tinaztepe Campus, 35390 Buca-Izmir, kevser.yilmaz@deu.edu.tr

${ }^{3}$ Dokuz Eylul University, Faculty of Business, Division of Production Management and Marketing, Tinaztepe Campus, 35390 Buca-Izmir, elif.cirkin@deu.edu.tr
} 


\section{INTRODUCTION}

As being a part of today's complex and vigorous business world, organisations embrace some methods and strategies enabling them to competitive and distinctive. Decision making processes play an important role in achieving these methods and strategies. Considering the fact that organisations need to deal with lots of variables and decision making processes have become more and more complex and complicated, hence optimization and determination methods have been developed in order to reach the best decision.

This research paper aims to probe the integration of such methods as Hesitant Fuzzy Analytic Hierarchy Process (HF-AHP) and Additive Ratio Assessment (ARAS) in decision making processes. HF-AHP solution approach is of great importance as it integrates various decision makers' opinions. HF-AHP method considers the priorities of the group as well as individual in making decisions. Moreover, it is a mathematical method including both qualitative and quantitative variables.This is also the case with the HF-AHP making it stronger than decision making methods. Another strong side of the method over other multi criteria methods are its flexibility, intuitive appeal to the decision makers and its ability to recognize inconsistencies (Ramanathan 2001). HF-AHP method also dimishes any possible prejudice in decision making. As for ARAS method, it is also a multicriteria decision making method that can be used in conjuction with such methods as TOPSIS, AHP, ANP. However, there has not been any work done by using both HF-AHP method and ARAS method together. Therefore, this study and its results could make contribution to the current literature.

Evaluation stages are very vague and ambiguous for managers based on their own subjective evaluation. Aim of the using HP-AHP method is to help manager in order to select best decision and with the help of ARAS method alternative evaluation could be assessed efficiently. So that complexity of making decision and selecting alternatives can be lowered with these methods. 
Within the scope of this study, in an attempt to gain a sound outlook on the history and structure of HF-AHP and ARAS methods a comprehensive literature review concerning the general understanding of these methods will be done. Furthermore, HF-AHP and ARAS methods and how these methods can be applied into decision making processes will be explained in a detailed manner. A case study will be conducted within a waste water treatment facility and explain the question of how to find the best supplier alternative among the five different supplier offerings in the virtue of improved benefit of the facility. Last, the conclusion and recommendations will be assessed to add further knowledge to the future research areas.

\section{LITERATURE REVIEW}

Pareto and Page (1971) is among the first academicians that discussed multiple criteria optimization and determination of priority and utility method which is known as a classical method. This classical method has improved with the contributions of some academicians (Keeney and Raiffa, 1976; Saaty, 1977; Seo, 1981). Multi criteria decision making (MCDM) method can be classified in different terms (Hwang and Yoon 1981; Larichev, 2000; Greco et al., 2005).

Larichev (2000) classified ARAS method as a quantitative measurement and AHP method as qualitative initial measurements. Saaty (1980) introduced AHP method to evaluate the best alternative. Intuitionistic fuzzy sets and hesitant fuzzy sets are sub-categories of the ordinary fuzzy sets. Hesitant Fuzzy Analytic Hierarchy Process can be described as effective and successful system in an effort to deal with uncertainty and gives opportunities to evaluate the criteria that has value between 0 and 1 . This method has been developed by Torra (2010) who is the first academician that defined hesitant fuzzy sets (HFSs).

Öztayşi et. al (2015) have solved supplier selection problem with using this method. Three different suppliers were evaluated by three experts under such four 


\section{A. ÖZDAĞOĞLU - K. YILMAZ - E. ÇİRKİN}

categories as reliability, responsiveness, agility, and cost. Based on these categories, optimum suppliers could be found.

HF-AHP method has been used for determining the performance values of service departments from the viewpoint of customers (Şenvar, 2017). Tüysüz and Şimşek (2017) have also benefitted hesitant fuzzy linguistic term set based on HFAHP in order to evaluate performance of the logistics firm which has 1000 branches in Turkey. Within the research paper of Tüysüz and Şimşek (2017), seven main categories including operational factors, human resources related factors, financial factors, customer relations related factors, sales and marketing related factors, safety and security related and cooperation with other units related factors were formed. Having evaluated these categories, safety and security related factors had been determined as the most important factor for the firm.

As for the studies applied ARAS method, Zavadskas and Turskis (2010) conducted a case study in Vilnius city in 2009 in order to assess microclimate in office rooms with using ARAS method. AHP and ARAS methods were utilised to disclose the best cultural heritage building in Vilnius city. (Kutut et. al, 2014). Medineckiene et. al (2015) employed ARAS method to identify sustainable building assessment/certification. Moreover, in order to select the best electricity generation technologies Štreimikienè et al. (2016) did a case study in Lithuania by using ARAS method. Institutional-political, economic, technological, social-ethics and environment protection were selected as assessment criterions to find out the best technology. According to the results of the studies, new nuclear power plant was found to be the best solution.

ARAS method could also be benefitted in various areas such as finding the best project for optimal fibre in telecommunication sector which was determined by Bakshi and Sarkar (2011) and measuring a faculty website's quality in Serbia by Stanujkic and Jovanovic (2012). Furthermore, Balezentiene and Kusta (2012) decided the best suitable fertilizing regimes in order to deal with greenhouse gas in grasslands by using ARAS method. Within the study of Dadelo et al. (2012), ARAS method was also benefitted in order to grade and select more appropriate 
security personnel. Another application of ARAS method in the selection of personnel would be that Zavadskas et al. (2012) evaluated the skills and abilities of project managers and used this method to choose the best ones.

In this research paper, these two methods including HF-AHP and ARAS shall be integrated and the originality of this paper will be highligted since these two methods have not been used togeher. The best machine alternative for the waste water treatment facility will be attempted to find. Next section discussed these two methods and their applications.

\section{HF-AHP METHOD}

Hesitant Fuzzy Analytic Hierarchy Process (HF-AHP) method is used for solving multi criteria decision making problems. HF-AHP method creates envelopes with hesitant fuzzy linguistic term sets. Different opinions of the decision makers construct these hesitant fuzzy linguistic term sets. Linguistic scale for HF-AHP method includes trapezoidal fuzzy numbers. Linguistic scale consisting of trapezoidal fuzzy numbers can be seen in Table 1 (Şenvar, 2017: 291).

Table 1. Linguistic Scale for HF-AHP

\begin{tabular}{|r|l|l|c|c|c|c|}
\hline & Linguistic Terms & & $a_{L}$ & $a_{M_{1}}$ & $a_{M_{2}}$ & $a_{R}$ \\
\hline 10 & Absolutely Very High Importance & AHI & 7,0000 & 9,0000 & 9,0000 & 9,0000 \\
\hline 9 & Very High Importance & VHI & 5,0000 & 7,0000 & 7,0000 & 9,0000 \\
\hline 8 & Essentially High Importance & ESHI & 3,0000 & 5,0000 & 5,0000 & 7,0000 \\
\hline 7 & Weakly High Importance & WHI & 1,0000 & 3,0000 & 3,0000 & 5,0000 \\
\hline 6 & Equally High Importance & EHI & 1,0000 & 1,0000 & 1,0000 & 3,0000 \\
\hline 5 & Exactly Equal & EE & 1,0000 & 1,0000 & 1,0000 & 1,0000 \\
\hline 4 & Equally Low Importance & ELI & 0,3333 & 1,0000 & 1,0000 & 1,0000 \\
\hline 3 & Weakly Low Importance & WLI & 0,2000 & 0,3333 & 0,3333 & 1,0000 \\
\hline 2 & Absolutely Low Importance & ESLI & 0,1429 & 0,2000 & 0,2000 & 0,3333 \\
\hline 1 & Very Low Importance & VLI & 0,1111 & 0,1429 & 0,1429 & 0,2000 \\
\hline 0 & Absolutely Very Low Importance & ALI & 0,1111 & 0,1111 & 0,1111 & 0,1429 \\
\hline
\end{tabular}

Reference: Şenvar, 2017: 291 


\section{A. ÖZDAĞOĞLU - K. YILMAZ - E. ÇİRKİN}

In the first step of HF-AHP, fuzzy pairwise comparison matrices have been constructed by collecting the decision maker's opinions. Linguistic terms can be written as follows (Öztayşi et al., 2015: 3-4).

$s_{0}$ : the lowest linguistic term according to Table 1

$s_{g}:$ the highest linguistic term according to Table 1

$s_{i}$ : the lowest linguistic term among the decision makers for comparison $s_{j}$ : the highest linguistic term among the decision makers for comparison $a_{L}:$ lower limit value of the trapezoidal fuzzy number $a_{M_{1}}$ : first most likely value of the trapezoidal fuzzy number $a_{M_{2}}:$ second most likely value of the trapezoidal fuzzy number $a_{R}:$ upper limit value of the trapezoidal fuzzy number a: lower limit value of the envelope $b$ : first most likely value of the envelope c: second most likely value of the envelope $d:$ upper limit value of the envelope

Then, the decision maker's opinions have been integrated by using fuzzy envelope approach. Equation 1 is used for finding the lower limit value of the fuzzy envelope which integrates the decision makers' different opinions.

$$
a=\min \left\{a_{L}^{i}, a_{L}^{i+1}, \ldots, a_{R}^{j}\right\}=a_{L}^{i}
$$

Equation 2 is used for finding the upper limit value of the fuzzy envelope which integrates the decision makers' different opinions.

$$
d=\max \left\{a_{L}^{i}, a_{L}^{i+1}, \ldots, a_{R}^{j}\right\}=a_{R}^{j}
$$


Weight value is necessary for computing the first most likely value of the fuzzy envelope which integrates the decision makers' different opinions. Ordered Weighted Averaging (OWA) operator is used for finding the weight vector.

$g$ : the number of terms in the linguistic scale

$j:$ the rank of highest evaluation of the decision makers

$i$ : the rank of lowest evaluation of the decision makers

$$
\begin{gathered}
W^{2} \text { : weight vector } \\
W^{2}=\left\{w_{1}^{2}, w_{2}^{2}, \ldots, w_{n}^{2}\right\}
\end{gathered}
$$

Weight values can be calculated as in Equation 3.

$w_{1}^{2}=\propto_{1}{ }^{n-1} ; w_{2}^{2}=\left(1-\propto_{1}\right) \propto_{1}{ }^{n-2} ; \ldots ; w_{n}^{2}=\left(1-\propto_{1}\right)$

The parameter in Equation 3 can be calculated as in Equation 4.

$$
\propto_{1}=\frac{g-(j-i)}{g-1}
$$

$b$ value can be calculated as in Equation 5 .

$$
\begin{aligned}
& i+1=j \Rightarrow a_{M}^{i} \\
& b=\left\{i+1 \neq j \wedge i+j \text { is even } \Rightarrow\left(w_{1}^{2}\right)\left(a_{M_{1}}^{\frac{i+j}{2}}\right)+\cdots+\left(w_{n}^{2}\right)\left(a_{M_{1}}^{i}\right)\right. \\
& i+1 \neq j \wedge i+j \text { is odd } \Rightarrow\left(w_{1}^{2}\right)\left(a_{M_{1}}^{\frac{i+j-1}{2}}\right)+\cdots+\left(w_{n}^{2}\right)\left(a_{M_{1}}^{i}\right)
\end{aligned}
$$

$c$ value can be calculated as in Equation 6.

$$
c=\left\{\begin{array}{l}
i+j \text { is even } \Rightarrow 2\left(a_{M_{1}}^{\frac{i+j}{2}}\right)-b \\
i+j \text { is odd } \Rightarrow 2\left(a_{M_{1}}^{\frac{i+j-1}{2}}\right)-b
\end{array}\right.
$$

Reciprocal values in the fuzzy pairwise comparison matrix can be calculated by using Equation 7.

$x$ : trapezoidal fuzzy number 


$$
\begin{array}{r}
y: \text { reciprocal of } x \\
x=(a, b, c, d) \Rightarrow y=\left(\frac{1}{d} ; \frac{1}{c} ; \frac{1}{b} ; \frac{1}{a}\right)
\end{array}
$$

Geometric means have been calculated for collaborative fuzzy pairwise comparison matrix as in Equation 8. The procedure has been applied all values in a trapezoidal fuzzy number one by one. This procedure gives the fuzzy importance levels of each criterion.

$$
e=\sqrt[t]{e_{1} \cdot e_{1} \cdot e_{1} \ldots e_{t}}
$$

Defuzzification operation has been made for finding the crisp importance levels of the criteria as in Equation 9.

$f_{l}$ : lower limit value of the fuzzy importance level

$f_{m_{1}}$ : first most likely value of the fuzzy importance level

$f_{m_{2}}$ : second most likely value of the fuzzy importance level

$f_{u}$ : upper limit value of the fuzzy importance level

$$
\text { D: defuzzified importance level of a criterion }
$$

$$
D=\frac{f_{l}+2 f_{m_{1}}+2 f_{m_{2}}+f_{u}}{6}
$$

These importance levels should be normalized by dividing the sum of defuzzified importance levels.

\section{Additive Ratio Assessment Method (ARAS)}

Additive Ratio Assessment (ARAS) method is one of the multi criteria decision making methods. ARAS method can be explained as follows (Štreimikienè et al., 2016, 149-150; Zavasdkas and Turskis, 2010, 163-165; Zavasdkas et al., 2010, 126-129).

The first step of ARAS method is to form the decision matrix.

i: alternative in the problem 


$$
\begin{gathered}
j: \text { selection criterion in the problem } \\
m: \text { number of alternatives in the problem } \\
n: \text { number of criteria in the problem }
\end{gathered}
$$

$x_{i j}$ : performance value of alternative $i$ with respect to the criterion $j$

$$
x_{0 j} \text { : optimal value with respect to the criterion } j
$$

$$
X: \text { the decision matrix }
$$

According to the variables explained above, the decision matrix can be formed as in Equation 10.

$$
X=\left[\begin{array}{cccc}
x_{01} & x_{02} & \ldots & x_{0 n} \\
x_{11} & x_{12} & \ldots & \ldots \\
\ldots & \ldots & \ldots & \ldots \\
x_{m 1} & \ldots & \ldots & x_{m n}
\end{array}\right] i=0,1,2, \ldots, m ; j=1,2,3, \ldots, n
$$

Optimal values according to beneficial and non-beneficial criteria can be found as in Equation 11.

$$
\left\{\begin{array}{c}
\max _{i} x_{i j} \text { is preferable } \Rightarrow x_{0 j}=\max _{i} x_{i j} \\
\min _{i} x_{i j}^{*} \text { is preferable } \Rightarrow x_{0 j}=\min _{i} x_{i j}^{*}
\end{array}\right.
$$

The next step of ARAS is to form the normalized decision matrix.

$$
\begin{gathered}
\bar{x}_{i j}: \text { normalized performance value of alternative } i \\
\text { with respect to the criterion } j \\
\bar{X}: \text { the normalized decision matrix }
\end{gathered}
$$

If the maximum value is preferable, the normalized performance value can be calculated as in Equation 12.

$$
\bar{x}_{i j}=\frac{x_{i j}}{\sum_{i=0}^{m} x_{i j}}
$$

If the minimum value is preferable, the normalized performance value can be calculated as in Equation 13. 
$x_{i j}=\frac{1}{x_{i j}^{*}} ; \bar{x}_{i j}=\frac{x_{i j}}{\sum_{i=0}^{m} x_{i j}}$

The normalized decision matrix can be constructed as in Equation 14.

$$
\bar{X}=\left[\begin{array}{cccc}
\bar{x}_{01} & \bar{x}_{02} & \ldots & \bar{x}_{0 n} \\
\bar{x}_{11} & \bar{x}_{12} & \ldots & \ldots \\
\ldots & \ldots & \ldots & \ldots \\
\bar{x}_{m 1} & \ldots & \ldots & \bar{x}_{m n}
\end{array}\right] i=0,1,2, \ldots, m ; j=1,2,3, \ldots, n
$$

The third step is to form the weighted normalized decision matrix.

$$
w_{j} \text { : the weight value of the criterion } j
$$

$\hat{x}_{i j}:$ weighted normalized performance value of alternative $i$

with respect to the criterion $j$

\section{$\hat{X}:$ the weighted normalized decision matrix}

It should be kept in mind that the sum of weight must be equal to 1 . The constraint about the sum of the weight values is in Equation 15.

$$
\sum_{j=1}^{n} w_{j}=1
$$

The weighted normalized performance values can be computed as in Equation 16.

$\hat{x}_{i j}=w_{j} x_{i j} ; i=0,1,2, \ldots, m$

The weighted normalized decision matrix can be formed as in Equation 17.

$$
\hat{X}=\left[\begin{array}{cccc}
\hat{x}_{01} & \hat{x}_{02} & \ldots & \hat{x}_{0 n} \\
\hat{x}_{11} & \hat{x}_{12} & \ldots & \ldots \\
\ldots & \ldots & \ldots & \ldots \\
\hat{x}_{m 1} & \ldots & \ldots & \hat{x}_{m n}
\end{array}\right] i=0,1,2, \ldots, m ; j=1,2,3, \ldots, n
$$

The next step is to determine the values of optimality function.

\section{$S_{i}$ : the value of optimality function with respect to alternative $i$}

The values of optimality function can be calculated as in Equation 18.

$$
S_{i}=\sum_{j=1}^{n} \hat{x}_{i j} ; i=0,1,2, \ldots, m
$$


The last step is to calculate the degree of the alternative utility.

$$
\begin{gathered}
S_{0}: \text { ideal value according to the decision matrix } \\
K_{i} \text { : the utility degree of the alternative } i
\end{gathered}
$$

The utility degrees can be found with Equation 19 .

$$
K_{i}=\frac{s_{i}}{S_{0}} ; i=0,1,2, \ldots, m
$$

Interval of the utility degree can be shown in Equation 20.

$0 \leq K_{i} \leq 1$

According to ARAS method, the best alternative has got the highest utility degree.

\section{APPLICATION}

In this study, data gathered from one of the waste water treatment facilities located in İzmir. The facility was established in 1990 and has been operating as a small-medium enterprise since then.

Within the facility, transformer centers, which are specialization areas, provide services in the field of supply and contracting of electricity transmission lines, turnkey infrastructure facilities, automatic irrigation systems, swimming pools and ecological ponds.

The facility manufactures such various products as air exhauster, conveyor, chemical preparation units and mixers, gratings and sieves, hydro-separator, automatic sediment filters, u.v. disinfection, oil retainers, package wastewater treatment tanks.

In order to prevent environmental pollution, which is one of the most important problems of our day, the facility has an important place in the sector with "intelligent wastewater treatment facilities" renewed every day with developing technology. 


\section{A. ÖZDAĞOĞLU - K. YILMAZ - E. ÇİRKİN}

Waterwaste pump is one of the most prominent supplied components among the purchasing decisions of the facility and used at both home and work places to disintegrate the waste materials in water. Supplier selection is of great importance since the facility relies heavily on suppliers. The supplier selection of the wastewater pump is regarded as a problem within the facility as there are five various wastewater pump suppliers including Alternative 1, Alternative 2, Alternative 3, Alternative 4, and Alternative 5. Based on the interview conducted with the general manager, engineer, and administrative affairs manager of the facility four crucial selection criteria were found to be previous experiences with the brand, maintenance time, quality, and lead time. Previous experiences with the brand as well as past performance of the purchased product play a key role in both the expected and experienced value (Pattersson and Spreng 1997). Maintenance time is also important in this sector because it takes a long time to repair the components of waterwaste pump. Thus, the managers aim to collaborate with the suppliers having less problems in maintenance issues. In order to enhance quality, the facility also seek to select suppliers providing with maximum quality and allocate orders between them.

In the first step of HF-AHP, fuzzy pairwise comparison matrices were been constructed by collecting the decision maker's opinions. Pairwise comparison matrix of the first decision maker can be seen in Table 2 .

Table 2. Pairwise Comparison Matrix of Decision Maker 1

\begin{tabular}{|l|l|l|l|}
\hline & Criterion 2 & Criterion 3 & Criterion 4 \\
\hline Criterion 1 & EHI & EHI & EHI \\
\hline Criterion 2 & & WLI & ESLI \\
\hline Criterion 3 & & & WLI \\
\hline
\end{tabular}

Pairwise comparison matrix of the second decision maker is shown in Table 3. 
Table 3. Pairwise Comparison Matrix of Decision Maker 2

\begin{tabular}{|l|l|l|l|}
\hline & Criterion 2 & Criterion 3 & Criterion 4 \\
\hline Criterion 1 & VHI & ESHI & EE \\
\hline Criterion 2 & & WLI & VLI \\
\hline Criterion 3 & & & ESLI \\
\hline
\end{tabular}

Pairwise comparison matrix of the third decision maker can be seen in Table 4 .

Table 4. Pairwise Comparison Matrix of Decision Maker 3

\begin{tabular}{|l|l|l|l|}
\hline & Criterion 2 & Criterion 3 & Criterion 4 \\
\hline Criterion 1 & VHI & ELI & EE \\
\hline Criterion 2 & & WLI & VLI \\
\hline Criterion 3 & & & ESHI \\
\hline
\end{tabular}

According to the decision makers' evaluations, fuzzy envelopes can be constructed. The fuzzy envelopes of the three decision makers are in Table 5.

Table 5. Fuzzy Envelopes of The Decision Makers

\begin{tabular}{|l|l|l|l|}
\hline & Criterion 2 & Criterion 3 & Criterion 4 \\
\hline Criterion 1 & $\begin{array}{l}\text { Between VHI and } \\
\text { EHI }\end{array}$ & $\begin{array}{l}\text { Between ESHI } \\
\text { and ELI }\end{array}$ & Between EHI and EE \\
\hline Criterion 2 & & WLI & $\begin{array}{l}\text { Between ESLI and } \\
\text { VLI }\end{array}$ \\
\hline Criterion 3 & & $\begin{array}{l}\text { Between ESHI and } \\
\text { ESLI }\end{array}$ \\
\hline
\end{tabular}

By using from equation 1 to equation 7, trapezoidal fuzzy sets of the fuzzy envelopes can be computed. The trapezoidal fuzzy sets for the first and second criterion columns of the fuzzy envelopes are in Table 6. 
Table 6. Trapezoidal Fuzzy Sets for Criterion 1 and Criterion 2

\begin{tabular}{|l|c|c|c|c|}
\hline & $\begin{array}{l}\text { Criterion 1 } \\
\text { a Value }\end{array}$ & $\begin{array}{l}\text { Criterion 1 } \\
\text { b Value }\end{array}$ & $\begin{array}{l}\text { Criterion 1 } \\
\text { c Value }\end{array}$ & $\begin{array}{l}\text { Criterion 1 } \\
\text { d Value }\end{array}$ \\
\hline Criterion 1 & 1,0000 & 1,0000 & 1,0000 & 1,0000 \\
\hline Criterion 2 & 0,1111 & 0,2903 & 0,3913 & 1,0000 \\
\hline Criterion 3 & 0,1429 & 1,0000 & 1,0000 & 3,0000 \\
\hline Criterion 4 & 0,3333 & 1,0000 & 1,0000 & 1,0000 \\
\hline & $\begin{array}{l}\text { Criterion 2 } \\
\text { a Value }\end{array}$ & $\begin{array}{l}\text { Criterion 2 } \\
\text { b Value }\end{array}$ & $\begin{array}{l}\text { Criterion 2 } \\
\text { c Value }\end{array}$ & $\begin{array}{l}\text { Criterion 2 } \\
\text { d Value }\end{array}$ \\
\hline Criterion 1 & 1,0000 & 2,5556 & 3,4444 & 9,0000 \\
\hline Criterion 2 & 1,0000 & 1,0000 & 1,0000 & 1,0000 \\
\hline Criterion 3 & 1,0000 & 3,0000 & 3,0000 & 5,0000 \\
\hline Criterion 4 & 3,0000 & 5,0000 & 7,0000 & 9,0000 \\
\hline
\end{tabular}

The trapezoidal fuzzy sets of the fuzzy envelopes for criterion columns three and four are in Table 7.

Table 7. Trapezoidal Fuzzy Sets for Criterion 3 and Criterion 4

\begin{tabular}{|l|c|c|c|c|}
\hline & $\begin{array}{l}\text { Criterion 3 } \\
\text { a Value }\end{array}$ & $\begin{array}{l}\text { Criterion 3 } \\
\text { b Value }\end{array}$ & $\begin{array}{l}\text { Criterion 3 } \\
\text { c Value }\end{array}$ & $\begin{array}{l}\text { Criterion 3 } \\
\text { d Value }\end{array}$ \\
\hline Criterion 1 & 0,3333 & 1,0000 & 1,0000 & 7,0000 \\
\hline Criterion 2 & 0,2000 & 0,3333 & 0,3333 & 1,0000 \\
\hline Criterion 3 & 1,0000 & 1,0000 & 1,0000 & 1,0000 \\
\hline Criterion 4 & 0,1429 & 0,6215 & 2,5579 & 7,1429 \\
\hline & $\begin{array}{l}\text { Criterion 4 } \\
\text { a Value }\end{array}$ & $\begin{array}{l}\text { Criterion 4 } \\
\text { b Value }\end{array}$ & $\begin{array}{l}\text { Criterion 4 } \\
\text { c Value }\end{array}$ & $\begin{array}{l}\text { Criterion 4 } \\
\text { d Value }\end{array}$ \\
\hline Criterion 1 & 1,0000 & 1,0000 & 1,0000 & 3,0000 \\
\hline Criterion 2 & 0,1111 & 0,1429 & 0,2000 & 0,3333 \\
\hline Criterion 3 & 0,1400 & 0,3909 & 1,6091 & 7,0000 \\
\hline Criterion 4 & 1,0000 & 1,0000 & 1,0000 & 1,0000 \\
\hline
\end{tabular}

Next step is to compute the geometric means for each row by using Equation 8 . The results can be seen in Table 8 . 
Table 8. Fuzzy Importance Levels of The Criteria

\begin{tabular}{|l|r|r|r|r|}
\hline & a Value & b Value & c Value & d Value \\
\hline Criterion 1 & 0,7598 & 1,2644 & 1,3623 & 3,7078 \\
\hline Criterion 2 & 0,2229 & 0,3429 & 0,4019 & 0,7598 \\
\hline Criterion 3 & 0,3761 & 1,0407 & 1,4823 & 3,2011 \\
\hline Criterion 4 & 0,6148 & 1,3277 & 2,0571 & 2,8316 \\
\hline
\end{tabular}

After finding fuzzy importance levels of the criteria in the decision making problem, crisp importance levels can be calculated with Equation 9. The crisp importance levels of the criteria are in Table 9.

Table 9. Crisp Importance Levels of The Criteria

\begin{tabular}{|l|r|r|}
\hline & Before Normalization & Normalized \\
\hline Criterion 1 & 1,6202 & 0,3133 \\
\hline Criterion 2 & 0,4121 & 0,0797 \\
\hline Criterion 3 & 1,4372 & 0,2779 \\
\hline Criterion 4 & 1,7026 & 0,3292 \\
\hline
\end{tabular}

After finding the crisp importance levels of the criteria, all alternatives have been analyzed according to criteria. The data set which includes criterion code, criterion name, measurement unit, beneficial or non-beneficial criteria information and the performance values of all alternatives is in Table 10. Table 10 exhibits optimal values according to beneficial and non-beneficial criteria as well. 
Table 10. Data Set for Alternatives

\begin{tabular}{|c|c|c|c|c|}
\hline & Beneficial & $\begin{array}{l}\text { Non- } \\
\text { Beneficial }\end{array}$ & $\begin{array}{l}\text { Non- } \\
\text { Beneficial }\end{array}$ & Beneficial \\
\hline $\begin{array}{l}\text { Measurement } \\
\text { Unit }\end{array}$ & 0-100 Scale & Day & Day & 0-100 Scale \\
\hline $\begin{array}{l}\text { Criterion } \\
\text { Code }\end{array}$ & Criterion 1 & Criterion 2 & Criterion 3 & Criterion 4 \\
\hline $\begin{array}{l}\text { Criterion } \\
\text { Name }\end{array}$ & $\begin{array}{l}\text { Previous } \\
\text { Experiences } \\
\text { with The } \\
\text { Brand }\end{array}$ & $\begin{array}{l}\text { Maintenance } \\
\text { Time }\end{array}$ & Lead Time & Quality \\
\hline $\bar{x}_{0 j}$ & 76,6667 & 7,0000 & 25,0000 & 93,3333 \\
\hline Alternative 1 & 76,6667 & 7,0000 & 30,0000 & 90,0000 \\
\hline Alternative 2 & 73,3333 & 20,0000 & 42,0000 & 83,3333 \\
\hline Alternative 3 & 46,6667 & 10,0000 & 25,0000 & 63,3333 \\
\hline Alternative 4 & 56,6667 & 20,0000 & 30,0000 & 73,3333 \\
\hline Alternative 5 & 76,6667 & 20,0000 & 42,0000 & 93,3333 \\
\hline
\end{tabular}

Owing to the fact that, some criteria are beneficial and some of them are nonbeneficial criteria, Equation 12 and Equation 13 should be used in this problem. $\bar{x}_{i j}$ values can be seen in Table 11 .

Table 11. $\bar{x}_{i j}$ Values

\begin{tabular}{|l|l|l|l|l|}
\hline & Beneficial & $\begin{array}{l}\text { Non- } \\
\text { Beneficial }\end{array}$ & $\begin{array}{l}\text { Non- } \\
\text { Beneficial }\end{array}$ & Beneficial \\
\hline $\begin{array}{l}\text { Measurement } \\
\text { Unit }\end{array}$ & 0-100 Scale & Day & Day & 0-100 Scale \\
\hline $\begin{array}{l}\text { Criterion } \\
\text { Code }\end{array}$ & Criterion 1 & Criterion 2 & Criterion 3 & Criterion 4 \\
\hline $\begin{array}{l}\text { Criterion } \\
\text { Name }\end{array}$ & $\begin{array}{l}\text { Previous } \\
\text { Experiences } \\
\text { with The } \\
\text { Brand }\end{array}$ & $\begin{array}{l}\text { Maintenance } \\
\text { Time }\end{array}$ & Lead Time & Quality \\
\hline$\overline{\boldsymbol{x}}_{\mathbf{0 j}}$ & 0,1885 & 0,2667 & 0,2059 & 0,1879 \\
\hline Alternative 1 & 0,1885 & 0,2667 & 0,1716 & 0,1812 \\
\hline Alternative 2 & 0,1803 & 0,0933 & 0,1225 & 0,1678 \\
\hline Alternative 3 & 0,1148 & 0,1867 & 0,2059 & 0,1275 \\
\hline Alternative 4 & 0,1393 & 0,0933 & 0,1716 & 0,1477 \\
\hline Alternative 5 & 0,1885 & 0,0933 & 0,1225 & 0,1879 \\
\hline
\end{tabular}


Then, the weighted normalized performance values can be computed as in Equation 16. The weight values in this equation have been found with HF-AHP method. The weighted normalized performance values are in Table 12.

Table 12. The Weighted Normalized Performance Values

\begin{tabular}{|l|l|l|l|l|}
\hline & Beneficial & $\begin{array}{l}\text { Non- } \\
\text { Beneficial }\end{array}$ & $\begin{array}{l}\text { Non- } \\
\text { Beneficial }\end{array}$ & Beneficial \\
\hline $\begin{array}{l}\text { Measurement } \\
\text { Unit }\end{array}$ & $\mathbf{0 - 1 0 0 \text { Scale }}$ & Day & Day & 0-100 Scale \\
\hline $\begin{array}{l}\text { Criterion } \\
\text { Code }\end{array}$ & Criterion 1 & Criterion 2 & Criterion 3 & Criterion 4 \\
\hline $\begin{array}{l}\text { Criterion } \\
\text { Name }\end{array}$ & $\begin{array}{l}\text { Previous } \\
\text { Experiences } \\
\text { with The } \\
\text { Brand }\end{array}$ & $\begin{array}{l}\text { Maintenance } \\
\text { Time }\end{array}$ & Lead Time & \multicolumn{1}{|l|}{ Quality } \\
\hline$\widehat{\boldsymbol{x}}_{\mathbf{0 j}}$ & 0,0591 & 0,0212 & 0,0572 & 0,0619 \\
\hline Alternative 1 & 0,0591 & 0,0212 & 0,0477 & 0,0597 \\
\hline Alternative 2 & 0,0565 & 0,0074 & 0,0341 & 0,0552 \\
\hline Alternative 3 & 0,0359 & 0,0149 & 0,0572 & 0,0420 \\
\hline Alternative 4 & 0,0437 & 0,0074 & 0,0477 & 0,0486 \\
\hline Alternative 5 & 0,0591 & 0,0074 & 0,0341 & 0,0619 \\
\hline
\end{tabular}

The optimality function values can be calculated according to Equation 18 by using the results in the previous table. The utility degrees can be calculated with Equation 19 by using the results in the previous table as well. The optimality function values the utility degrees for each alternative are in Table 13.

Table 13. The Optimality Function Values and the Utility Degrees

\begin{tabular}{|l|c|c|}
\hline & $S_{i}$ & $K_{i}$ \\
\hline Ideal Value & 0,1994 & 1,0000 \\
\hline Alternative 1 & 0,1876 & 0,9411 \\
\hline Alternative 2 & 0,1532 & 0,7685 \\
\hline Alternative 3 & 0,1500 & 0,7524 \\
\hline Alternative 4 & 0,1474 & 0,7392 \\
\hline Alternative 5 & 0,1624 & 0,8146 \\
\hline
\end{tabular}

According to Table 13, alternative 1 is the best option. 
An interpretation can be made that the alternative 1 is clearly ahead, followed by number 5 , and all other alternatives are far behind. Therefore, it is evident that alternative 1 is by far the best choice based on both the optimality values and utililiy degrees.

\section{CONCLUSION}

The complexity of the decision making processes strongly urge for a more harmonious and pellucid approach regarding the area of supplier selection as unfavourable deciosions could lead to both direct and indirect impediments. Within this study, supplier selection of a water waste treatment facility for the water waste pumps was attempted to be analysed. Out of the five alternative suppliers and five selection criterions including previous experiences with the brand, maintenance time, quality, and lead time, optimum supplier was found with the help the integration of such methods as HF-AHP and ARAS. According to the results of these methods used, alternative 1 was determined as the most optimum result on behalf of the facility. This study constitutes an exemplary application for HF-AHP and ARAS methods which are among the multi-criteria decision making methods. Since these two methods have not been integrated in the existing literature yet, our study and its results could lead to contribution in the context of practical implications. Furthermore, this application intends to not only use these methods for similar decisions but also to use other decision-making problems to be encountered in the future. Accordingly, our study points to several potential fruitful directions for future research areas. It can be expanded with other variables such as cost, social responsibility, warranty, and technical abilities. Last but not least, apart from supplier selection, other business decisions including resource allocation, strategic planning and project/risk management, employment selections can be also made by using HF-AHP and ARAS techniques. 


\section{REFERENCES}

BAKSHI, T., SARKAR, B. (2011), "MCA based performance evaluation of project selection", arXiv preprint arXiv:1105.0390.

BALEZENTIENE, L., KUSTA, A. (2012), "Reducing greenhouse gas emissions in grassland ecosystems of the central Lithuania: multi-criteria evaluation on a basis of the ARAS method", The Scientific World Journal, 2012.

DADELO, S., TURSKIS, Z., ZAVADSKAS, E. K., DADELIENE, R. (2012), "Multiple criteria assessment of elite security personal on the basis of aras and expert methods", Journal of Economic Computation and Economic Cybernetics Studies and Research, 46(4), 65-88.

GRECO, S., FIGUEIRA, J., EHRGOTT, M. (2005), Multiple criteria decision analysis, Springer's International series.

HWANG, C. L., YOON, K. (1981), "Multiple criteria decision making", Lecture Notes in Economics and Mathematical Systems, 186, 58-191.

KEENEY R.L., RAIFFA H. (1976), Decision with Multiple Objectives: Preferences and Value Tradeoffs, New York, John Wiley and Sons

KUTUT, V., ZAVADSKAS, E. K., LAZAUSKAS, M. (2014), “Assessment of priority alternatives for preservation of historic buildings using model based on ARAS and AHP methods", Archives of Civil and Mechanical Engineering, 14(2), 287-294.

LARICHEV, O. (2000), Decision-making theory and methods, Moscow: Logos (in Russian).

MEDINECKIENE, M., ZAVADSKAS, E. K., BJÖRK, F., TURSKIS, Z. (2015), "Multi-criteria decision-making system for sustainable building assessment/certification", Archives of Civil and Mechanical Engineering, 15(1), 11-18. 
ÖZTAYŞI, B., ONAR, S. Ç., BOLTÜRK, E., KAHRAMAN, C. (2015, August), "Hesitant fuzzy analytic hierarchy process", In Fuzzy Systems (FUZZIEEE), 2015 IEEE International Conference on (pp. 1-7). IEEE.

PARETO, V., PAGE, A. N. (1971), Translation of Manuale di economia politica (Manual of political economy), AM Kelley. ISBN 978-0-678-00881-2.

PATTERSSON, P. G., SPRENG, R. A. (1997), "Modelling the relationship between perceived value, satisfaction and repurchase intentions in a business-tobusiness, services context: an empirical examination", International Journal of Service Industry Management, 8(5), 414-434.

RAMANATHAN, R.(2001), A note on the use of the analytic hierarchy process for environmental impact assessment. Journal of Environmental Management, 63: 27-35.

SAATY, T. L. (1977), "A scaling method for priorities in hierarchical structures”, Journal of Mathematical Psychology, 15(3), 234-281.

SAATY, T. L. (1980), Analytic Heirarchy Process, Wiley StatsRef: Statistics Reference Online.

ŞENVAR, Ö. (2017), "A Systematic Customer Oriented Approach based on Hesitant Fuzzy AHP for Performance Assessments of Service Departments", Advances in Fuzzy Logic and Technology 2017: Proceedings of: EUSFLAT- 2017 - The 10th Conference of the European Society for Fuzzy Logic and Technology, September 11-15, 2017, Warsaw, Poland IWIFSGN'2017 - The Sixteenth International Workshop on Intuitionistic Fuzzy Sets and Generalized Nets, September 13-15, 2017, Warsaw, Poland, 3. Cilt.

STANUJKIC, D., JOVANOVIC, R. (2012), "Measuring a quality of faculty website using ARAS method". In Proceeding of the International Scientific Conference Contemporary Issues in Business, Management and Education 2012 (pp. 545-554).

ŠTREIMIKIENĖ, D., ŠLIOGERIENĖ, J., and TURSKIS, Z. (2016), "Multicriteria analysis of electricity generation technologies in Lithuania", Renewable Energy, 85, 148-156. 
TORRA, V. (2010), "Hesitant fuzzy sets", International Journal of Intelligent Systems, 25(6), 529-539.

TÜYSÜZ, F., ŞIMŞEK, B. (2017), “A hesitant fuzzy linguistic term sets-based AHP approach for analyzing the performance evaluation factors: An application to cargo sector", Complex and Intelligent Systems, 3(3), 167-175.

ZAVADSKAS, E. K., TURSKIS, Z. (2010), "A new additive ratio assessment (ARAS) method in multicriteria decision-making", Technological and Economic Development of Economy, 16(2), 159-172.

ZAVADSKAS, E. K., VAINIŪNAS, P., TURSKIS, Z., TAMOŠAITIENĖ, J. (2012), "Multiple criteria decision support system for assessment of projects managers in construction", International Journal of Information Technology and Decision Making, 11(02), 501-520. 